\title{
BULGARIAN EXPERIENCE IN THE DEVELOPMENT OF SOCIAL ADAPTATION OF MILITARY PERSONNEL, DISCHARGED FROM MILITARY SERVICE AND THEIR FAMILIES
}

\author{
Venelin Terziev \\ Corresponding Member of the Russian Academy of Natural History, Moscow, Russia, Prof. D.Sc. \\ (Ec.), D.Sc. (National Security), D.Sc. (Social Activities), Ph.D., National Military University, Veliko \\ Tarnovo, Bulgaria; University of Rousse, Rousse, Bulgaria, terziev@skmat.com
}

\begin{abstract}
This paper, originating from the understanding and approaches to the term „adaptation“, explores and analyses the stages of the social adaptation process of military personnel, discharged from service, which along with getting to know the psychological and professional aspects of the process allows the elaboration of a practical model of social and psychological adaptation of this population category. The scientific aspirations of the authors of this paper are focused on the specific characteristics of military service and the specific competences, which require the implementation of specific methods and means of professional orientation, preparation for settling and acquiring a new profession in the changed living environment.
\end{abstract}

Keywords: military personnel, discharged form service; social adaptation.

\section{INTRODUCTION}

The content of the processes of social adaptation of military reservists and the members of their families and the issues, associated with the social work with them predetermine as insufficient the practice to receive only social (socio-psychological, socio-legal, socio-economic, etc.) protection and realization of various types of social support (educational, medical, consumer, psychological, etc.). This is the administrative approach, leading to waste of efforts and resources, to duplicating of efforts of specialists of different profile and bringing about the common person, in their regular condition, to be considered outside the frame of clients of social work, and its offices to start their work only when the person goes into the category of the risk group of troubled individuals.

The essence of the social work with servicepersons, discharged from military service, and the members of their families during the transition period lies in the social adaptation of this category of the population to the new conditions of life in a civil environment, in a specific social medium, which is implemented in the following stages: preparation, entry, adaptation and development. The successful result of the social adaptation of a specific serviceperson lies in the psychological acceptance of the new conditions of life, in retaining and developing of their social status and finding a job that provides the corresponding to this status 
material living conditions for their family.

Such understanding of the social work with military reservists and the members of their families determines the logic of the further research, the essence of which consists of:

Analysis of the development history of the social work with the specified category of the population;

Identification of the contradictions, disadvantages and difficulties, as well as the objective and subjective errors in its development;

Development of experimental model for social adaptation of servicepersons, discharged from military service and the members of their families, in accordance with the understanding of it as a socio-pedagogical phenomenon.

\section{BULGARIAN EXPERIENCE IN THE DEVELOPMENT OF SOCIAL ADAPTATION OF MILITARY PERSONNEL, DISCHARGED FROM MILITARY SERVICE AND THEIR FAMILIES}

Based on the tracing back the current practice, it is noteworthy that in the early 1990s of the last century, when drastic reforms in the structures of the military department were carried out, involving reduction of the personnel, tasks related only to organization of conversion training / rehabilitation training and employment of the military reservists, were assigned to all organizations and institutions, involved in the social adaptation of the military personnel, discharged from military service. The regulation itself is in confirmation of this, if there was any during this period. The names of the various documents themselves suggest that at this stage the question for a comprehensive approach to solving a given problem has not been raised. Experts in the field, at the start of their activities consider that the possibilities of rehabilitation training in a civilian specialty allow the serviceperson, discharged from military service a decent work in the civil sector.

In particular, the main directions of work at this initial stage are:

Organization of the different type of schools (from training centres and courses to different institutes for rehabilitation training);

Establishing normative legal basis for the organization of this rehabilitation training;

Searching and opening of new job positions;

Creating special „military” employment markets - specific recruitment offices for the military personnel, discharged from military service;

Establishing bodies for coordination of the system for rehabilitation training and finding a job for the military personnel, discharged from military service;

Creating suitable material and technical, as well as organizational conditions for the operation of this system, etc.

Leading priority of the formed system is the rehabilitation training of the military personnel, discharged from military service in civilian specialties. The methodological basis for selection of this priority is a postulate that a new profession for the military reservist ensures their social adaptation to civil life.

The number of the military personnel, discharged from military service in certain periods caused by the restructuring of the Bulgarian army continues to grow, while the number of job vacancies in the public sector falls sharply. As a result, problems, which in previous years did not require special intervention, have now appeared.

The necessity for wider consideration of the process of social adaptation of the military personnel, discharged from military service, as well as the implementation of the relevant work with the members of their families, has arisen.

The experience shows that the military personnel, discharged from military service, successfully carry out business activity development and realization of other regional social and economic projects. Establishing a system of vocational guidance, rehabilitation training, employment and social adaptation is also necessary in connection with the massive growth of the unacceptably large part of the people on allowance, at the expense of the potentially active part of the population. Furthermore, the creation of favourable conditions to accelerate the adaptation of the military reservists and the members of their families to the civil life, which allows them to turn into one of the active and economically independent categories of the population, is recognized as appropriate. 
Unfortunately, the establishment of this system is accompanied by delay of the organizational measures without the mandatory prediction, often as a late response to the problem, without good coordination of the efforts of the involved organizations, institutions and individuals.

The formed system is too controversial. It is not of complex nature and has inaccurately selected priorities, leading to the accumulation of a series of errors and reducing the potential of the measures taken, to significant increase of the cost price of the process of social adaptation in respect of the individual serviceperson.

As a result of this activity, in Bulgaria there are three relatively independent and competing systems for rehabilitation training of military personnel, discharged from military service.

The first of them is the state system. It includes educational institutions of higher education engaged in the training and rehabilitation training (prequalification) of persons, including servicepersons, discharged from military service, in civilian specialties, licensed by the National Agency for Vocational Education and Training.

An important direction in the development of this system is the training of servicepersons in the higher military schools, which ends with a diploma in one of the civilian disciplines. Such a decision is based on the opinion that a second civil degree raises the level of social protection of the young officer.

The disadvantage of such approach is demonstrated by the practice in recent years. It concerns the following:

At the first place, a degree in a civilian specialty, obtained by the young officer in the higher military school is in compliance with the relevant professional standard only at the time of graduation of the higher school. When performing their job duties, related to the primary (military) specialty for many years, the officer practically deskills in the civil sector (except for the general technical, engineering, medical, financial, economic and other professions). As a result, after the discharge, the level of their professional competence in the civil sector is so low that to find a job in accordance with the qualifications obtained ten years ago, is almost impossible.

At the second place, the results show that the narrow professional specialization acquired by the majority of servicepersons during the military service, is often unnecessary in civilian terms. Moreover, the mass nonoverloading of the manufacturing capacities of the enterprises, as well as personnel cuts lead to flooding of the employment market with qualified skilled workforce, where the discharged from military service serviceperson feels too "uncomfortable". The most common proposals for military reservists, as a rule, are the positions of a security guard, freight forwarder, collector, etc. Moreover, the employers do not care if their future employee has a degree or special knowledge.

In the third place, the research shows that the degree of compliance of the new types and the content of the work of the servicepersons discharged from military service with the degree of their education and qualification, obtained during the military service, is low enough.

In the fourth place, the civilian specialty degree obtained by the young officers within the higher military schools contributes objectively to the massive leave of the Bulgarian army, which significantly weakens the military organism of the country and leads to unjustified resource spending.

The specifics of the military service often do not allow the members of the families of the servicepersons to work in the places of their residence, primarily in their main specialties. After discharging from military service and determining the permanent residence, the members of the family of the serviceperson, which also have lost their professional competence, find themselves in an uncompetitive position in the labor market, compared with their peers from the civil society. This fact determines the necessity of inclusion of the family members of the servicepersons in the system of rehabilitation training for new specialties or increase of their qualifications.

By analyzing the activities of the civil educational institutions, including vocational training centers in the field of rehabilitation training of military reservists and theirs family members (primarily aiming at their further employment under the new conditions of life) a conclusion could be made that this activity is not the main activity for the civil universities, and therefore it is paid significantly less attention than necessary. In the market conditions for rehabilitation training of servicepersons, the civil schools for higher education require additional financing, which appears to be very burdensome for the state given the current budget deficit.

Those categories that are forced (due to lack of other housing) to live in closed or remote from the major cities and villages areas, are excluded from the state system for rehabilitation training of military reservists and the members of their families. These servicepersons do not have the chance to undergo rehabilitation 
training at the respective universities or vocational training centers.

Furthermore, the specific system for rehabilitation training military reservists and the members of their families is not oriented towards solving the problem of finding employment. As a result, its effectiveness is insignificant.

In this way, the state system for rehabilitation training of servicepersons is generally unable to solve independently the tasks for professional reorientation, rehabilitation training / retraining and employment of military reservists and the members of their families in civilian professions.

Nowadays these issues cannot be resolved independently by the state system either under the terms of a functioning market economy.

The disadvantages of the state system for rehabilitation training of servicepersons lead objectively to the formation of principally different system - extra-state / extra-budgetary. It is oriented towards solving of these issues at the expense of attracting funding from European programs for human resources development, from targeted funding of training and rehabilitation training of military personnel, discharged from military service by private and foreign organizations, from individual payment of rehabilitation training of military reservists and the members of their families, etc. In many cases, the system uses the funds provided in the National Action Plan for Employment of the Ministry of Labor and Social Policy.

The loss of the state monopoly on education and employment of people, including the military reservists, as well as the limitations of these options in the budget system, are favourable for the creation of the extrabudgetary system. The competition between them contributes to the initial formation of the extra-budgetary system for rehabilitation training of military reservists as complementary to the state /budget/ system, and in a number of positions - as an alternative to it. This system allows more flexible and operational respond to the changes in the labor market and workforce. In view of mutual interest for the establishment of relationships between the military personnel, discharged from military service and the employers, the goal is to provide rehabilitation training to the discharged servicepersons in specialties, providing guaranteed job. The extrabudgetary system for rehabilitation training / retraining of the servicepersons and their families becomes namely the initiator of the idea of combining the problems of vocational guidance, rehabilitation training and employment in a single system for their social adaptation to the conditions of civilian life. Nowadays, this idea turns into a commonly accepted perspective. In Bulgaria however, there is no national strategy or plan for the implementation of the process of social adaptation.

The extra-budgetary system includes a number of schools and educational institutions in their capacity of independent legal entities that seek to spread their influence primarily on potential risk groups of unemployed persons, including the discharged servicepersons, using also the forms of distance learning. It includes the organization of employment markets, as well as other similar initiatives. In many cases, the activities of the individual institutions from the extra-budgetary system are directed to the creation of new job positions with a view to the specifics of the local and regional needs and the existing potential.

Among the disadvantages of the system in question the most significant are:

- Lack of material and financial, as well as organizational and technical resources for the organization of its activities; Ifragmented nature of the functioning of the various sub-systems and institutions;

- Lack of professionally trained staff of the organizers of the learning process in educational institutions and systems;

- Lack of strategy for its development and bodies able to provide coordination of all work within the country;

- Contradictions in the relations with the budgetary system and the state structures;

- Underdevelopment of the normative legal basis for the operation of the given system;

- Weakness of its information and analytical, as well as prognostic provision;

- Errors in the determination of priorities in the specialties for training, etc.

Nevertheless, the extra-budgetary system for rehabilitation training/retraining/ of the military personnel, discharged from military service, which nowadays develops in a system for their professional orientation, prequalification and employment, supplementing the budget /state/ system, allows the significant expansion of the potential opportunities for the discharged service persons and the members of their families to obtain new civilian specialties and employment in accordance with them. This system contributes significantly to solving the problems, related to social adaptation of the military personnel, discharged from military service, to the new conditions of life, and to the decrease of the social tension both among them and among those 
servicepersons who are about to be discharged from military service. The system on its own however, is unable to solve the complex problems associated with the reduction of the Bulgarian army.

Along with the formation of the budgetary and extra-budgetary system for rehabilitation training and employment of the military personnel, discharged from military service, and the members of their families, a third system is formed- the investment system. Its features are:

- Allocating of resources from different organizations and funds;

- Program targeted financing of the rehabilitation training and employment of the

- Servicepersons;

- Priority to economic and market professions in the retraining of the military reservists;

- Limiting the terms for their rehabilitation training to a few months;

- Attraction of foreign specialists of different profile to the realization of the goals and

- Objectives of this system;

- Choice of orientation to the interaction with the budgetary and extra-budgetary system, etc.

The latter feature of the investment system is a key to the further development of the common system of vocational guidance, rehabilitation training /retraining / and employment of the military personnel, discharged from military service, and the members of their families in Bulgaria.

In the third place, the formation of the system for social adaptation of the military reservists and the members of their families, which encompasses primarily their rehabilitation training for new specialties, is accompanied by the development of its infrastructure (training centres, etc.), based generally on the potential of the schools for higher education of the Ministry of education and Science. On the one hand, the universities are located in the big cities, which automatically restrict the access to the rehabilitation training of the majority of the discharged servicepersons the members of their families who live permanently in remote from the university centres areas. On the other hand, there are the various administrative obstacles and failings in the implementation of the coordination of this specific activity.

The brief historical overview of the development of the social work with the discharged servicepersons and the members of their families, along with an indication of the contradictions, weaknesses, difficulties, failings in its development, allows the trends, both positive and negative, in the development of the social adaptation, to be derived.

Among the positive trends deserving attention are:

- Compensation of the shortage of funds through funding under European programs;

- Gaining experience to solve these problems by various government structures;

- Attracting different institutions (Ministry of Labor and Social Policy, Ministry of Education and Science, Ministry of Defence, the Social Assistance Agency and its territorial divisions, Employment Agency and its territorial divisions, etc..) to the social adaptation of the military personnel, discharged from military service and the members of their families;

- Establishing specialized organizational structures or units, engaged in solving the problems of the given population category / formed risk groups in the employment market, as the former servicepersons also are / other.

The negative trends of the development of this system are:

- The predominant orientation of the state institutions to rehabilitation training of the military personnel, discharged from military service and the members of their families and the limitation of the process of their social adaptation with retraining and partly employment;

- Lack of coordination of the state institutions with the activities of other organizations, dealing with the problems of social adaptation of the military reservists, including public and nongovernmental organizations;

- Unresolved hitherto controversies between the institutions;

- High degree of dependence of the activities on social adaptation of the specified population category by the amount of funding / determined by the budget frame of the National Action Plan for Employment/;

- Lack of trained personnel to manage the process of social adaptation of the military personnel, 
discharged from military service and the members of their families, etc.

All these circumstances require the development of a concept and model for social adaptation of this category of the population, based on the best experience of the activities of different organizations in the country, the positive foreign experience, as well as the results of their own experienced and expert work.

Although within the rehabilitation training / retraining / of the military personnel, discharged from military service and the members of their families other issues of their social adaptation are also solved, they are not assigned directly, though sometimes indicated. The autonomous solving of these issues does not provide the necessary results from the reintegration of the given category of the population in the civil social medium.

Such state of affairs determines the need to develop a comprehensive model of social adaptation of the military personnel, discharged from military service and the members of their families.

Complex model for social adaptation of the military personnel, discharged from military service and the members of their families

The formation of a complex model for social adaptation of the military reservists and the members of their families is implemented on a specific social background, created in the early and mid-90s of the last century, and is related to the overall reorganization and restructuring of the Bulgarian society. In particular this concerns the following specific characteristics.

The 90s of the last century, along with political and socio-economic changes across the world, and with Bulgaria's transition to a market economy, are the years when the radical military reform was implemented in our country, which resulted in the reduction of the armed forces. The actions taken led to the discharge of large part of the active population among officers, sergeants, petty officers and the members of their families. This led to increased social tension in society. Despite the efforts, made by the state and various social groups, the implementation of a program for social adaptation for the military personnel, discharged from military service, this group remains at risk in the labor market.

An important feature of the social situation within the field of work with military personnel, discharged from military service and the members of their families is practically the general failure of the existing social institutions in the complex solving of the problems of this process in the new conditions of life and their involvement in active work life in the market conditions.

Thus, the social situation created in this field determines another concept of the social adaptation of the military reservists and the members of their families.

In accordance with these specificities, the basic conceptual ideas of the specific model have the following priorities:

At the first place, the term "social adaptation of servicepersons" is used for the first time as a basic priority instead of the earlier term "rehabilitation training" and employment of the servicepersons. The approbation of the given conceptual priority is implemented within the program "Social adaptation".

The structure of the program in Bulgaria includes the following units (Table. 1):

Program and operational unit, consisting of a program director and program coordinators;

Financial accounting department, including a financial director and a cashier accountant;

Centers for rehabilitation training and social adaptation /CRTSA/, a total of 4, in the cities of Sofia, Plovdiv, Sliven and Veliko Tarnovo, managed by chief regional coordinators. They employ coordinators for psychosocial adaptation, professional orientation, business consultants, legal advisers and administrators;

Regional information centers /RIC/, as at the beginning of 2003 two RICs work with CRTSA Veliko Tarnovoin the cities of Shoumen and Varna, and one RIC works with CRTSA Sliven- in the city of Stara Zagora.

The so presented program can be considered as a model for the complex approach (and therefore represents a complex model) to solving the problems of the military personnel, discharged from military service and the members of their families. Besides, no goal is set for all discharged from the Bulgarian army servicepersons to adapt to civilian life or for helping their families. The goal of the program is to develop a mechanism for complex solving of the social problems of the specified category of the population of the country, the creation of a complex model (or several models) of the organization of this process on the basis of self-support. 
IJASOS- International E-Journal of Advances in Social Sciences, Vol. IV, Issue 12, December 2018

Table 1. Structure of the „Social adaptation” program

\begin{tabular}{|c|c|c|c|}
\hline \multicolumn{2}{|c|}{$\begin{array}{c}\text { Program and operational unit } \\
\text { Program director } \\
\text { Program coordinator } \\
\text { Chief coordinator of the CRTSA }\end{array}$} & \multicolumn{2}{|c|}{$\begin{array}{l}\text { Financial accounting department } \\
\text { Financial director } \\
\text { Cashier- accountant }\end{array}$} \\
\hline CRTSA Sofia & CRTSA Plovdiv & CRTSA Sliven & CRTSA Veliko Taronvo \\
\hline Chief coordinator & Chief coordinator & Chief coordinator & Chief coordinator \\
\hline $\begin{array}{l}\text { Coordinator for } \\
\text { professional orientation }\end{array}$ & $\begin{array}{l}\text { Coordinator for } \\
\text { professional orientation }\end{array}$ & $\begin{array}{l}\text { Coordinator for } \\
\text { professional orientation }\end{array}$ & $\begin{array}{l}\text { Coordinator for } \\
\text { professional orientation }\end{array}$ \\
\hline $\begin{array}{l}\text { Coordinator for } \\
\text { professional orientation }\end{array}$ & $\begin{array}{l}\text { Coordinator for } \\
\text { professional orientation }\end{array}$ & $\begin{array}{l}\text { Coordinator for } \\
\text { professional orientation }\end{array}$ & $\begin{array}{l}\text { Coordinator for } \\
\text { professional orientation }\end{array}$ \\
\hline $\begin{array}{c}\text { Coordinator for } \\
\text { psychosocial adaptation }\end{array}$ & $\begin{array}{c}\text { Coordinator for } \\
\text { psychosocial adaptation }\end{array}$ & $\begin{array}{c}\text { Coordinator for } \\
\text { psychosocial adaptation }\end{array}$ & $\begin{array}{c}\text { Coordinator for } \\
\text { psychosocial adaptation }\end{array}$ \\
\hline \multirow{5}{*}{$\begin{array}{l}\text { Business consultant } \\
\text { Legal advisor } \\
\text { Administrator } \\
\text { Assistant administrator }\end{array}$} & Legal advisor & Administrator & Legal advisor \\
\hline & Administrator & & Administrator \\
\hline & & & \\
\hline & & & \\
\hline & & $\begin{array}{c}\text { RIC -Stara Zagora } \\
\text { Coordinator }\end{array}$ & $\begin{array}{l}\text { RIC-Varna } \\
\text { Coordinator }\end{array}$ \\
\hline
\end{tabular}

At the second place, the complex approach is not only a complex solution of the problems, related to the adaptation of people to the new conditions, but also a change of the society as well. This includes: the introduction of new, more advanced "production" technologies, training of personnel, social work organization, social and educational activities. The results from the implementation of such projects include the socioeconomic development of the regions for planning at the expense of the inclusion in this process of economically active and highly professional personnel of military reservists and the members of their families; establishment of social partnership at the expense of reducing the tension in this social group; infrastructure development of the civil society, etc.

At the third place, the complex nature of the proposed model and the program based on it is determined by the socio-pedagogical value orientations in its structure and content.

The starting point in the creation of the complex model of social adaptation of servicepersons and their families lies in the concept of a "model" itself. According to the logic and methodology of the science, it is analogical to a specific fragment of the natural or social reality, product of the human culture, conceptualtheoretical model. This analogue is to preserve and expand the knowledge (information) for the original, for the design of the original, for its restructuring or management.

Therefore, the complex model of social adaptation of the military personnel, discharged from military service and the members of their families is namely part of the socio-pedagogical practice that can and should be studied, designed, approbated and implemented in this reality with new qualities, properties and characteristics.

The specific model is constructed in such way as to be in conformity with all essential requirements of the modelling technology: to be objective conformity of the modelled subject and able to replace it in certain respects; to provide expert verification of the results, which to be interpreted at different stages by the same instructive terms of the military social work and social pedagogy.

And since scientifically the social adaptation is considered as a system, as a process and as an activity, its subject is the military reservists and the members of their families (women and children). Besides, this model, on the one hand, implies an inseparable unity of the members of the family when it comes to implementation of all kinds of activities, and on the other- the initial assuming by the family of a status of a subject with its own social adaptation to civil life.

When taking into account the fact that the model is a simplified, "contracted" model of a real event, 
phenomenon, process, the model for social adaptation of the servicepersons is considered in two plans: a structural-component (organization- subject) and structural-functional (main functions as directions for the social adaptation). Moreover, the model also plays a role as a method of knowledge of the social practice, and as a method for its restructuring in the field of social adaptation of the military personnel, discharged from military service and the members of their families. The model is a "mental image or materially realized system", which by displaying or reproducing the subject of study is able to replace it in such a way that the study of the system provides us with new information for the subject.

The structural- component composition of the model involves combining of all units which take part in the process of social adaptation (as a means for their financial support) and an instrument for development of entrepreneurial activity. Furthermore, other organizations, such as educational, research, social, women's associations, territorial authorities for local government and other organizations become structural elements of the model as well. Besides, priority is given to those organizations that have been created by former servicepersons and the members of their families, or those in which this category of the population is significantly represented.

The structural-functional composition of the model implies the unification of the main directions of the social adaptation of the military personnel, discharged from military service and the members of their families, as well as selection among the main directions of those which are the basis of the model and are the most significant for its amendment, the most resistant in real conditions of life activity in the different conditions of the society.

The basis of social adaptation of servicepersons covers: professional orientation; psychological rehabilitation /psychological support/; socio-psychological and socio-pedagogical adaptation, attracting the military personnel, discharged from military service and the members of their families to small businesses, the creation of support structures for small businesses, employment and if necessary- their professional retraining /prequalification/.

The content of the model for social adaptation of military reservists and the members of their families determines its reference to the pattern model, as it is used to study and change the regulatory properties of the actually existing in the practice of the military social work subject. In the experimental work, the model for social adaptation of the military reservists and the members of their families is also used in its capacity as a substitute model, as with its help a research constructive work is conducted.

In accordance with the requirements of the technology of the socio-pedagogical modelling, the development of the complex model of social adaptation of the military personnel, discharged from military service and the members of their families is conducted through the consecutive change of three related with each other stages.

In the first stage (stage of forming the model), separation of key components is performed (of the structure and functions) of the activity for social adaptation of the servicepersons (its content, directions, forms and methods) which are then subject to changes in the model - research and constructive restructuring.

The second stage (stage of restructuring the model) is in connection with the modification of its individual properties (of the structure and functions) in relation to the conditions of the research and the presented above social background. The timing frame of the present stage of the research takes three years and the content of the activity at this stage compiles the content of the trial experimental work.

The third stage (the stage for transferring the results on the subject) is a set of recommendations, practical measures and proposals, prepared and partially realized in a process of the trial experimental work on the formation of the complex model for social adaptation of military reservists. At this stage, verification of the authenticity, validity, effectiveness and viability of the resulting model is also performed.

The process for development, approbation and implementation of the model for social adaptation of military personnel, discharged from military service and the members of their families shall be carried out with consideration of the specifics of the social pedagogical modelling.

For example, this model is not only a pattern model, but also a substitute model. As a pattern model, it is used with reference to the existence of major subsystems and activities in the social adaptation of military personnel, discharged from military service and members of their families for the reason of studying and restructuring of the regulatory properties of this activity. As a substitute model, it is used for a creative, constructive work on the problems of social adaptation of military personnel, discharged from military service and the members of their families.

Furthermore, recognizing social pedagogical models as values, goals, directions for further development, the 
complex model of social adaptation of the military personnel, discharged from military service is twofold in its nature. In the process of its formation and approbation it is indicated that interconnected types of activities are not always strictly fixed in their sequence.

In this regard, the developed model on the one hand is invariant, as the presented types of activities and directions for social adaptation of military personnel, discharged from military service and the members of their families constitute its main content. On the other hand, the model varies, as the sequence of these activities and directions of social adaptation of the respective category of the population is built in accordance with the social needs of every military reservist and their families. It's about the individual profile of social adaptation for each individual.

In implementing the Program, the main focus is on places with compact residence of the families of servicepersons of different types (structural and geographical composition of the model), located within the differentiated city areas of residential buildings, as well as the nondifferentiated areas within the city.

An important conceptual aspect of modelling of the social adaptation of the military personnel, discharged from military service and the members of their families is the theoretical foundation of the social work, setting its priorities and content, nature and approaches, principles, methods and forms.

The classification, built on such basis allows presenting them as a set of the most popular theories of the social work, separate formulations of which lie in the theoretical justification of the complex model of the social adaptation of the military personnel, discharged from military service and the members of their families:

Psychologically oriented theories of the social work (existential, humanistic, psychodynamic, crisisinterventive, behavioural, permitting, bioenergetic, body-oriented; dianetic; socionic; psycho-synthetic);

Sociologically oriented theories of the social work (system-wide, socio-ecological, radical, Marxist);

Complex (interdisciplinary) theories of the social work (vitally-oriented, cognitive, conflict logical; sociopedagogical; sociocultural).

Each of these theories has its content, target orientation, methods of learning and changes in the social practice. Formation and implementation of the model for social adaptation of the military reservists and the members of their families suggests a reference to the formulation of these theories, not by the uniform application of only one of them, but through the complex use of those ideas from each theory, which provide effective operation of this model.

Some of the leading conceptual formulations of the complex model, reflecting the social pedagogical values, are the principles of social adaptation of the military personnel, discharged from military service and the members of their families.

The principle of personal, socially active approach to their social adaptation implies:

Placement of the specific serviceperson in the centre of the activity for social adaptation, as a member of the family, within the family and together with their family;

Consideration of all needs of the serviceperson (and any member of their family) within the work for social adaptation: individual, physiological, material, social, personal, professional, universal, cultural, educational etc.;

Organization of the work on their social adaptation through its orientation primarily to the specific (region, municipality, city, district, etc.) social medium, considering the specifics of the surrounding social environment;

Active participation in the social adaptation of the military personnel, discharged from military service and the members of their families themselves, their switch from passive consuming to active transforming activity in the new social environment of their place of residence.

Full reporting and addressing of all human needs is possible only if there is family support and that is why the core of all processes for social adaptation lies in the work with the family. After all, the family should not only be a user of a particular set of social services, it should also be their producer. It is namely the active participation of family members in solving their problems, together with the particular specialist from the respective Social Work Office that favors the active development of the person, the military social medium and the mechanisms of their interaction.

The principle of integration in the social adaptation of the military personnel, discharged from military service and the members of their families suggests: 
Bringing together the different vertical (institutional) structures for social work (sociopedagogical, medical, economic, psychological, cultural and educational, social protection, etc.) to attract of the military personnel, discharged from military service and the members of their families in the social production activities directly into their new social medium;

Integration of interagency and differentiated (specialized) social work authorities in complex social authorities (centres) in the specific areas of the populated areas;

Providing multidisciplinary and complementary activity of the work for social adaptation of the military reservists and the members of their families in their places of residence in the new environment;

Forming a structure for working on the social adaptation of the military personnel, discharged from military service, with medical, psychological and pedagogical character, helping them to solve major social problems at the level of the individual person in connection with their transition from military to civilian social medium.

The principle of pedagogical approach in the work for social adaptation of the military reservists and the members of their families envisages the use of social, pedagogical theory as the complex foundation of the organization of the whole work. It suggests:

Preventive nature of the social adaptation, which begins before the dismissal of servicemen from military service and their transformation into military reservists, as its focus is not so much on solving the acute social problem of their families (without giving up on this kind of activity) but on the immediate diagnostic and preventive actions in the new environment, in the specific civil social medium;

Introduction of the profession "social teacher " in the Bulgarian army and the corresponding positions in the social infrastructure of military units/military educational institutions and where the family members of the servicepersons and military reservists live; one of its functions must be the immediate work on the training of servicepersons and their families for the transition from military to civilian social medium;

Organization of the impacts on all aspects of the life and activities of the military personnel, discharged from military service and the members of their families; uniting efforts of the school, family, military and industrial pedagogy and the pedagogy of communication, preventive pedagogy, pedagogy of creativity and free time into a unified military, social pedagogy for the benefit of the social education of the servicepersons and the members of their families, their social, pedagogical tracking from the entry into military service to their successful integration into the civil social medium after its completion.

The principle of sociocultural orientation of the social adaptation of the military personnel, discharged from military service and the members of their families suggests:

The use of the term "culture of the social medium" as a goal and criterion for assessing the level of development of the human inhabited environment, including by the military personnel, discharged from military service and the members of their families in their particular places of residence; use of this concept as a qualitative characteristic of the way of solving the issues of their social adaptation and meeting the needs of its subjects; its application as an indicator of the development of one or another social environment;

Orientation of the work on social adaptation to formation of a multilateral model for sociocultural behaviour of the military reservists and the members of their families in both the military and civilian social medium. The multidimensional model of socio-cultural behaviour suggests the formation of a culture of the military work, culture of social communication and interaction, culture of the family life, lifestyle and behavior, general culture of the military etiquette, culture of the speech and appearance of the military man (even the military reservist), culture of their feelings etc.

On the other hand, the work on social adaptation of the military reservist and the members of their families and social work with them in their new civil social medium are oriented towards the formation of a multilateral model of culture in various spheres of social consciousness (legal aesthetic, ecological, economic, political, educational, moral, artistic, physical, etc.);

Using the potential of cultural and educational activities, the cultural institutions of the civil society as the main instrument of social adaptation of the relevant category of the population.

The principle of the scientific merit on social adaptation of the military personnel, discharged from military service and the members of their families suggests:

Research of domestic and foreign experience in order to determine the content, organization and methodology of this work, summary, analysis and reporting of this experience in the organization of this kind of activity in the civil social medium; appropriate use of the experience of social work across society and the different categories of the population; preparation of summarized methodical recommendations of the 
specialists involved in work with the military reservists and the members of their family;

Organization of consistent research methodology, theory, methods and practice of social adaptation to a particular category of the population with a view to the specifics of its development as a combination of various types of activities;

Preparation of social educators and social workers based on the best Russian and foreign practice, on the basis of specifically organized research.

The process of social adaptation is carried out in two main directions: on the one hand, the specifics of directions and technologies of social adaptation of the military reservists and the members of their families are indicated, on the other hand, the common to all categories of the population, which change the social medium or the profession, trends and technologies are sought.

Among the common technologies is the technology of socio-pedagogical diagnosis, evaluation, prediction, modelling, design, and programming. This group includes technologies for: planning, realization of the goals and value orientations, receiving feedback and providing information of the cognitive and transforming activity on social adaptation of the discharged military personnel and their families. Collectively, they represent a closed-loop process of the technological process of the work on social adaptation of each category of population, which is in a state of transition from one set of activity conditions to another.

The specific technologies for social adaptation of the military personnel, discharged from military service and the members of their families, apply to the technologies in their professional orientation; rehabilitation; sociopsychological rehabilitation; socio-pedagogical adaptation; the attraction to small businesses; support of small businesses; employment; rehabilitation training and monitoring.

Common and interconnected general and specific technologies represent the transforming potential of an integrated model of social adaptation of the military reservists and the members of their families.

An important issue is the potential of an integrated model for social adaptation of the military personnel, discharged from military service and the members of their families, as a qualitative and intermodal technology model for social adaptation of persons changing their social medium, profession, way of life. In particular, the opportunities for application of a model, where migrants from underdeveloped regions of the country; among persons released from prisons; the unemployed, etc., are approbated.

The model for social adaptation of the military personnel, discharged from military service and the members of their families, developed and piloted in this way, is complex in nature, sociopedagogical in content, technological in its practical relevance, inter-ministerial and interinstitutional in its level of interaction. Such approach to the development and implementation of the model in the framework of the Program for social adaptation of the military personnel, discharged from military service and the members of their families seriously differs from all preceding models, designs, concepts and programs, initiated for the purpose of military social work with the military personnel, discharged from military service and the members of their families (Terziev, 2017; Terziev, 2017a, pp.1375-1399; Terziev, 2017b, pp.1362-1377; Terziev, 2017c, pp.1378-1392; Terziev, 2017d, pp.1352-1361; Terziev, 2017e, pp.914 - 922; Terziev, 2017f, pp. 923 - 935; Terziev, 2017g, pp.49-59; 9. Terziev, 2017h, pp.452-458; Terziev, 2017i, pp.786-796; Terziev, 2017j, pp. 997-1024; Terziev, Bogdanov, Madanski, Stefanov, 2017k, pp.85-97; Banabakova, Georgiev, 2017l, pp. 4651; Banabakova, Georgiev, 2017m, pp. 462-467; Banabakova, Georgiev, 2017n, pp. 84-99; Banabakova, Georgiev, 2017o, pp. 468-483; Terziev, Madanski, Georgiev, 2017p, pp. 923-927; Terziev, Madanski, Georgiev, 2017q, pp. 1051-1055; Terziev, Nichev, Stoyanov, Georgiev, 2017r, pp. 888-892; Banabakova, Georgiev, 2017s, pp. 37-47).

\section{CONCLUSION}

In conclusion, the problem for modifying the structure of one or another area of the state and society, of one or another sector of a particular sphere, refers to the problems of the dynamic development of the country and is determined by their dependence on the economy, the level of development of science and technology, etc. On the other hand, the qualitative and quantitative characteristics of one or another sphere and its sectors are determined by external factors: the international, political and economic relations, the degree of threat to national security, etc.

Reducing and restructuring of the Bulgarian army is determined precisely by these processes, therefore it has an objective character. However, realization of this process, its organization and management have a subjective nature, determined by the human factor.

These and other reasons are the basis for the development of a comprehensive model of social adaptation of the military personnel, discharged from military service, which is acceptable to those servicepersons who 
integrate into civilian social medium in the places of their residence. In this case, the leading approach from the position for providing targeted assistance to specific groups of the population, changes to a position for active transformation: including the military reservists and the members of their families in an active socioeconomic activity in the places of their residence in the institutions of the civil social medium, i.e. full account of the potential of the indicated group of the population.

This model could be implemented and deployed in its main elements across the country, under different conditions and work with different groups of the military personnel, discharged from military service. This controversial issue in the public space- if the social adaptation of the military personnel, discharged from military service and the members of their families is myth or realitycould be resolved in favour of the reality and effectiveness of the researched by us issues, through the relevance of an integrated approach, interaction between institutions, direct interest of the state and the business (Terziev, Madanski, Georgiev, 2017t, pp. 748-753; Terziev, Madanski, Georgiev, 2017u, pp. 743-747; Madanski, Georgiev, 2017v, pp. 4-13; Madanski, Georgiev, 2017w, pp. 43-51; Terziev, Dzhumalieva, 2016a, s.233-253; Terziev, 2014, s.176-183; Terziev, 2014a, s.183-191; Terziev, 2014b, s.192-204; Terziev, 2014c, pp.194-201; Terziev, 2014d, s.201210; Terziev, 2014e, s.210-222).

\section{REFERENCE LIST}

Terziev, Venelin. (2017). Opportunities for improving the efficiency of the socialadaptation of servicemen discharged from military service in Bulgaria. // Catalogue of the scientific, educational and methodical literature presented by authors at the I-XXXIV All-Russian book exhibitions held by Academy of Natural History, Exposition on the Frankfurter Buchmesse 2017, XXVII, Moskow, Academy of Natural History, 2017.

Terziev, Venelin. (2017a). Social adaptation as a social process in the adaptation of military personnel. // Journal of Economic Geography, International Health, Oxford University Press, 17, 2017, N 6(2), pp.1375-1399, ISSN 1468-2702, Source Normalized Impact per Paper (SNIP): 2.358, SCImago Journal Rank (SJR): 2.909.

Terziev, Venelin. (2017b). Insights into some examples of triggering the process of social adaptation. // International Health, Oxford University Press, 9, 2017, N6 (2), pp.1362-1377, ISSN 1876-3413, Source Normalized Impact per Paper (SNIP): 0.721, SCImago Journal Rank (SJR): 0.835.

Terziev, Venelin. (2017c). Examples of modelling social adaptation of servicemen discharged from military service. // International Health, Oxford University Press, 9, 2017, N 6 (2), pp.1378-1392, ISSN 18763413, Source Normalized Impact per Paper (SNIP): 0.721, SCImago Journal Rank (SJR): 0.835.

Terziev, Venelin. (2017d). Studying different aspects of social adaptation. // International Health, Oxford University Press, 9, 2017, N6 (2), pp.1352-1361, ISSN 1876-3413, Source Normalized Impact per Paper (SNIP): 0.721, SCImago Journal Rank (SJR): 0.835.

Terziev, Venelin. (2017e). Social adaptation and socialization as processes: characteristics, principles, factors. // European Journal of International Law, Oxford University Press, 28, 2017, N 4 (2), pp.914 922, ISSN 0938-5428, Source Normalized Impact per Paper (SNIP): 1.424, SCImago Journal Rank (SJR): 0.722.

Terziev, Venelin. (2017f). Factors affecting the process of social adaptation. // European Journal of International Law, Oxford University Press, 28, 2017, N 4 (2), pp. 923 - 935, ISSN 0938-5428, Source Normalized Impact per Paper (SNIP): 1.424, SCImago Journal Rank (SJR): 0.722.

Terziev, Venelin. (2017g). A new view on social adaptation of the military, discharged from military service in Bulgaria. // IJASOS- International E-Journal of Advances in Social Sciences, April 2017, 3, 2017, N 7, ISSN 2411-183X, pp.49-59.

Terziev, Venelin. (2017h). Factors affecting the process of social adaptation. // 3rd International Conference on Advanced Research in Business and Social Sciences 2017 29th to 30th March, 2017, 1, 2017, ISBN: 978-967-13620-2-0, pp.452-458.

Terziev, Venelin. (2017i). A New View on Social Adaptation of the Military, Discharged From Military Service in Bulgaria. // Intcess 2017, 4th International conference on education and social sciences, 6-8 February, 2017 - Istanbul, Turkey, 2017, ISBN 978-605-64453-9-2, pp.786-796. 
IJASOS- International E-Journal of Advances in Social Sciences, Vol. IV, Issue 12, December 2018

Terziev, Venelin. (2017j). A new view on social adaptation of the military, discharged from military service in Bulgaria. // Oxford Review of Economic policy, 33, 2017, N 4 (2), pp. 997-1024, ISSN 0266-903X. Source Normalized Impact per Paper (SNIP): 1.014 SCImago Journal Rank (SJR): 0.974 Impact factor: 0.764 5-Yr impact factor: 1.629.

Terziev, V., Bogdanov, P., Madanski, V., Stefanov, S. (2017k). Approaches to social adaptation of servicemen discharged of military service. // Eight international scientific conference Knowledge without borders, 8-10 април 2016 г., Банско, България. International Journal Scientific papers, 12, 2016, N 2, ISSN1857-92, pp.85-97.

Banabakova, V., Georgiev, M. (2017I). Military professional forming of the cadets at Vasil Levski National Military University. // IJAEDU- International E-Journal of Advances in Education, April 2018, Turkey, International Organization Center of Academic Research, www.ocerints.org, Istanbul, Turkey, 2018, pp. 46-51, 4, 2018, N 10, e-ISSN: 2411-1821.

Banabakova, V., Georgiev, M. (2017m). Military professional forming of the cadets at Vasil Levski National Military University. // Proceedings of INTCESS2018- 5th International Conference on Education and Social Sciences 5-7 February 2018- Istanbul, Turkey, International Organization Center of Academic Research, www.ocerints.org, Istanbul, Turkey, 2018, pp. 462-467, ISBN :978-605-82433-2-3.

Banabakova, V., Georgiev, M. (2017n). The role of the Balanced Scorecard as a tool of strategic management and control. // IJAEDU- International E-Journal of Advances in Education, April 2018, International Organization Center of Academic Research, www.ocerints.org, Istanbul, Turkey, 2018, pp. 84-99, 4, 2018, N 10, e-ISSN: 2411-183X.

Banabakova, V., Georgiev, M. (20170). The role of the Balanced Scorecard as a tool of strategic management and control. // Proceedings of INTCESS2018- $5^{\text {th }}$ In-ternational Conference on Education and Social Sciences 5-7 February 2018- Istanbul, Turkey, International Organization Center of Academic Research, www.ocerints.org, Istanbul, Turkey, 2018, pp. 468-483, ISBN :978-605-824332-3.

Terziev, V., Madanski, V., Georgiev, M. (2017p). Offset implementation impact on technology transfer in Bulgaria. // IJAEDU- International E-Journal of Advances in Education, International Organization Center of Academic Research, www.ocerint.org, 3, 2017, N 9, pp. 923-927, e-ISSN: 2411-18.

Terziev, V., Madanski, V., Georgiev, M. (2017q). Offset as an economic operation and a trade practice. // IJAEDU- International E-Journal of Advances in Education, International Organization Center of Academic Research, www.ocerint.org, 3, 2017, N 9, pp. 1051-1055, e-ISSN: 2411-18.

Terziev, V., Nichev, N., Stoyanov, E., Georgiev, M. (2017r). A general principle of the development process of Balanced scorecards as an instrument of control. // IJAEDU- International E-Journal of Advances in Education, International Organization Center of Academic Research, www.ocerint.org, 3, 2017, N 9, pp. 888-892, e-ISSN: 2411-18.

Banabakova, V., Georgiev, M. (2017s). Problems and perspectives in Military professional education and realization of cadets in Bulgaria. // Journal of Innovations and Sustainability, Innovations and Sustainability Academy. 3, 2017, N 4, pp. 37-47, ISSN 2367-8127 (CD-ROM), ISSN 2367-8151 (online).

Terziev, V., Madanski, V., Georgiev, M. (2017t). Offset as an economic operation and a trade practice. // Proceedings of ADVED 2017- 3rd International Conference on Advances in Education and Social Sciences 9-11 October 2017- Istanbul, Turkey. International Organization Center of Academic Research, www.ocerint.org, 2017, pp. 748-753, ISBN: 978-605-82433-0-9.

Terziev, V., Madanski, V., Georgiev, M. (2017u). Offset implementation impact on technology transfer in Bulgaria. // Proceedings of ADVED 2017- 3rd International Conference on Advances in Education and Social Sciences 9-11 October 2017- Istanbul, Turkey International Organization Center of Academic Research, www.ocerint.org, 2017, pp. 743-747, ISBN: 978-605-82433-0-9.

Madanski, V., Georgiev, M. (2017v). The offset as a specific sort of economic activity. // Scientific journal «Economics and finance». Academic publishing house of the Agricultural University, Priority research areas: Collection of scientific articles, 2017, pp. 4-13, ISBN 978-617-7214-53-2.

Madanski, V., Georgiev, M. (2017w). Study of the effect of offset implementation on technology transfer in the Republic of Bulgaria. // Scientific journal «Economics and finance». Academic publishing house of the Agricultural University, Priority research areas: Collection of scientific articles, 2017, pp. 43-51, 
IJASOS- International E-Journal of Advances in Social Sciences, Vol. IV, Issue 12, December 2018

ISBN 978-617-7214-53-2.

Terziev, V., Dzhumalieva, A. (2016a). Dostapnost do pazara na truda i sotsialna adaptatsiya na osvobodenite ot balgarskata armiya voennosluzheshti i chlenovete na tehnite semeystva. // XI Mezhdunarodnoy nauchnoy konferentsii „Innovatsii v tehnologiyah i obrazovanii", 18-19 Marta 2016 g., Kuzbasskiy gosudarstvennayy tehnicheskiy universitet im. T.F. Gorbacheva, Belovo, 4, 2016, ISBN 978-5-906888-04-4, s.233-253 (Терзиев, В., Джумалиева, А. Достъпност до пазара на труда и социална адаптация на освободените от българската армия военнослужещи и членовете на техните семейства. // XI Международной научной конференции „Инновации в технологиях и образовании", 18-19 Марта 2016 г., Кузбасский государственный технический университет им. Т.Ф. Горбачева, Белово, 4, 2016, ISBN 978-5-906888-04-4, с.233-253).

Terziev, Venelin. (2014). Possible aspects of occupational and psychological adaptation of the military, discharged from military service and their families to a new activity life cycle. // Mezhdunarodnaya nauchno-prakticheskaya konferentsiya „Nauka XXI veka: teoriya, praktika, perspektivay”, 6 lyunya 2014, Ufa, Rossiya, 2014, ISBN 978-5-906763-30-3, s.176-183 (Terziev, Venelin. Possible aspects of occupational and psychological adaptation of the military, discharged from military service and their families to a new activity life cycle. // Международная научно-практическая конфреренция „Наука XXI века: теория, практика, перспективы", 6 Июня 2014, Уфра, Россия, 2014, ISBN 978-5-90676330-3, c.176-183).

Terziev, Venelin. (2014a). Realities of implementing the social adaptation procees of military personnel, discharged form service in Bulgaria. // Mezhdunarodnaya nauchno-prakticheskaya konferentsiya „Nauka XXI veka: teoriya, praktika, perspektivay”, 6 lyunya 2014, Ufa, Rossiya, 2014, ISBN 978-5906763-30-3, s.183-191 (Terziev, Venelin. Realities of implementing the social adaptation procees of military personnel, discharged form service in Bulgaria. // Международная научно-практическая конференция „Наука XXI века: теория, практика, перспективы”, 6 Июня 2014, Уфа, Россия, 2014, ISBN 978-5-906763-30-3, c.183-191).

Terziev, Venelin. (2014b). Bulgarian experience in the development of social adaptation of military personnel, discharged from military service and their families. // Mezhdunarodnaya nauchnoprakticheskaya konferentsiya „Nauka XXI veka: teoriya, praktika, perspektivay”, 27 lyunya 2014, Ufa, Rossiya, 2014, ISBN 978-5-906763-30-3, s.192-204 (Terziev, Venelin. Bulgarian experience in the development of social adaptation of military personnel, discharged from military service and their families. // Международная научно-практическая конференция „Наука XXI века: теория, практика, перспективы”, 27 Июня 2014, Уфа, Россия, 2014, ISBN 978-5-906763-30-3, с.192-204).

Terziev, Venelin. (2014c). Possible aspects of occupational and psyhological adaptation of the military, discharged from military service and their families to a new activity life cycle. // Международная научно-практическая конференция: 27 Июня 2014, „Наука и Современность”, Уфа, Россия, 2014, ISBN 978-5-906763-48-8, pp.194-201 (Terziev Venelin. Possible aspects of occupational and psyhological adaptation of the military, discharged from military service and their families to a new activity life cycle. // Mezhdunarodnaya nauchno-prakticheskaya konferentsiya: 27 lyunya 2014, „Nauka i Sovremennosty”, Ufa, Rossiya, 2014, ISBN 978-5-906763-48-8, pp.194-201).

Terziev, Venelin. (2014d). Realities of implementing the social adaptation process of military personnel, discharged from service in Bulgaria. // Международная научно-практическая конференция 27 Июня 2014, „Наука и Современность”, Уфа, Россия, 2014, ISBN 978-5-906763-48-8, с.201-210 (Terziev, Venelin. Realities of implementing the social adaptation process of military personnel, discharged from service in Bulgaria. // Международная научно-практическая конференция 27 Июня 2014, „Наука и Современность”, Уфа, Россия, 2014, ISBN 978-5-906763-48-8, с.201-210).

Terziev, Venelin. (2014e). Bulgarian experience in the development of social adaptation of military personnel, discharged from military service and their families. // Mezhdunarodnaya nauchnoprakticheskaya konferentsiya 27 Iyunya 2014, „Nauka i Sovremennosty”, Ufa, Rossiya, 2014, ISBN 978-5-906763-48-8, s.210-222 (Terziev, Venelin. Bulgarian experience in the development of social adaptation of military personnel, discharged from military service and their families. // Международная научно-практическая конференция 27 Июня 2014, „Наука и Современность”, Уфа, Россия, 2014, ISBN 978-5-906763-48-8, с.210-222). 